\title{
PHYSICAL DEMAND IN SOCCER SMALL-SIDED GAMES: INFLUENCE OF TEAM COMPOSITION
}

\author{
DEMANDA FÍSICA DE PEQUENOS JOGOS NO FUTEBOL: INFLUÊNCIA DO CRITÉRIO DE COMPOSIÇÃO \\ DASEQUIPES
}

\author{
DEMANDA FÍSICA EN PEQUEÑOS PARTIDOS EN EL FÚTBOL: INFLUUENCIA DEL CRITERIO DE COMPOSICIÓN \\ DELOSEQUIPOS
}

\begin{abstract}
Gibson Moreira Praça' (iD) (Physical Education Professional) Marcelo Vilhena Silva² (D) (Physical Education Professional) Raphael Brito e Sousa' (iD) (Physical Education Professional) Juan Carlos Pérez Morales ${ }^{1}$ (D) (Physical Education Professional) Pablo Juan Greco ${ }^{1}$ (D) (Physical Education Professional)
\end{abstract}

1. Universidade Federal de Minas Gerais (UFMG), Escola de Educação Física, Fisioterapia e Terapia Ocupacional, Sports Department. Belo Horizonte, MG, Brazil. 2. Pontifícia Universidade Católica (PUC), Belo Horizonte, MG, Brazil.

\section{Correspondence:}

Pablo Juan Greco.

EEFFTO - Escola de Educação Física, Fisioterapia e Terapia Ocupacional. Av. Pres. Antônio Carlos, 6627 Campus - Pampulha, Belo Horizonte, MG, Brazil. 31270-901.grecopj@ufmg.br

\begin{abstract}
Introduction: Small-sided games (SSG) are used as training tools for physical conditioning in soccer. To date, however, it is unknown whether team composition affects athletes' physical performance. Specifically, based on the differences presented by players of different positions, it is expected that the use of positional status as a criterion for team composition will affect players' physical performance. Objective: To compare the physical demands of SSG in teams composed of young soccer players in the same position or different positions. Methods: $12 \mathrm{U}-15$ soccer players participated in the study. The athletes performed 3v3 SSGs under two conditions: teams in which the athletes played in the same position (i.e. three defenders), and teams in which the players took up different positions (i.e. defender, midfielder and attacker). Data were obtained on total distance traveled, distance in speed zones, and accelerations, using GPS devices. The data were analyzed using the paired t-test, comparing the two experimental conditions. Results: There was higher physical demand among defenders and midfielders when the SSG was performed with athletes playing in the same position, in terms of distances covered in different speed zones. However, there were no differences in relation to acceleration actions. Conclusion: Team composition affects the physical performance of soccer athletes during $3 \mathrm{v} 3$ SSG. Level of evidence IV; Case series.
\end{abstract}

Keywords: Task performance and analysis; Soccer; Physical education and training.

\section{RESUMO}

Introdução: Pequenos jogos (PJ) são utilizados como meios de treinamento físico no futebol. Até o momento, contudo, desconhece-se se compor as equipes de diferentes formas para a realização dos jogos gera impacto no desempenho físico dos atletas. Especificamente, baseando-se nas diferenças apresentadas pelos jogadores de diferentes posições, espera-se que a utilização do estatuto posicional como critério para composição das equipes modifique o desempenho físico dos jogadores. Objetivo: Desta forma, o presente estudo teve como objetivo comparar a demanda física dos pequenos jogos em equipes compostas por atletas de mesma posição ou de posições diferentes praticados por jovens atletas de futebol. Métodos: Participaram do estudo 12 atletas de futebol da categoria sub-15. Os atletas realizaram PJ na estrutura $3 \mathrm{v} 3 \mathrm{em}$ duas condições: com equipes compostas por atletas de mesma posição (por exemplo, três defensores) ou com equipes compostas por atletas de posições diferentes (por exemplo, um defensor, um meio-campista e um atacante por equipe). Analisaram-se os dados referentes à distância total percorrida è à distância em faixas de velocidade e acelerações obtidos através do equipamento de GPS. Os dados foram comparados entre as situações experimentais por meio do teste t pareado. Resultados: Os resultados apontaram maior demanda física entre os defensores e meio-campistas quando esses realizaram os PJ com atletas da mesma posição em relação às distâncias percorridas em diferentes faixas de velocidade, sem diferença nas ações de aceleração. Conclusão: 0 critério de composição das equipes altera o desempenho físico dos atletas de futebol durante o pequeno jogo $3 \mathrm{v3}$. Nível de evidência IV; Série de casos.

Descritores: Análise e desempenho de tarefas; Futebol; Educação física e treinamento.

\section{RESUMEN}

Introducción: Pequeños partidos (PP) son utilizados como medios de entrenamiento físico en el fútbol. Hasta el momento, sin embargo, se desconoce si componer a los equipos de diferentes formas para la realización de los partidos genera impacto en el desempeño físico de los atletas. Específicamente, basándose en las diferencias presentadas por los jugadores de diferentes posiciones, se espera que la utilización del estatuto posicional como criterio para la composición de los equipos modifique el desempeño físico de los jugadores. Objetivo: De esta forma, el presente estudio tuvo como objetivo comparar la demanda física de los pequeños partidos en equipos compuestos por atletas de la misma posición o de posiciones diferentes practicados por jóvenes atletas de fútbol. Métodos: Participaron en el estudio 12 atletas de fútbol de la categoría sub-15. Los atletas realizaron PP en la estructura 3 contra 3 en dos condiciones: con equipos compuestos por jugadores de la misma posición (por ejemplo, tres defensores), o con equipos compuestos por jugadores de posiciones diferentes (por ejemplo, un defensor, un mediocampista y un atacante por equipo). 
Se analizaron los datos referentes a la distancia total recorrida y la distancia en rangos de velocidad y aceleraciones, obtenidos a través del equipamiento de GPS. Se compararon los datos entre las situaciones experimentales por medio del test t pareado. Resultados: Los resultados apuntaron mayor demanda física entre defensores y mediocampistas cuando esos realizaron los PP con atletas de la misma posición con relación a las distancias recorridas en diferentes rangos de velocidad, sin diferencia en las acciones de aceleración. Conclusión: El criterio de composición de los equipos altera el desempeño físico de los atletas de fútbol durante el pequeño partido de 3 contra 3. Nivel de evidencia IV;

\section{Serie de casos.}

Descriptores: Análisis y desempeño de tareas; Fútbol; Educación y entrenamiento físico.

\section{INTRODUCTION}

During the last decades, the use of small-sided games (SSG) has been suggested to develop players' physical skills. The SSG allows replicating, at least partially, the match physical, physiological, technical, and tactical demands, in a game-based context ${ }^{1,2}$. It is known that changes in variables such as pitch size ${ }^{3}$ and the number of players per team lead to different training adaptations. In addition, different teams' composition criteria (i.e., criteria used to form teams), such as players' aerobic power 4,5 , technical skills ${ }^{4}$, and tactical knowledge can be adopted to balance teams. The most common strategy to form balanced teams comprises the division of players according to playing positions (e.g., defender, midfielder and forward) 6,7, although, in some cases, complementary criteria can be adopted, such as players' tactical knowledge ${ }^{8}$.

The physical demands of SSG are often investigated using the data provided by GPS devices ${ }^{9,10}$. Although data obtained from GPS equipment with sampling rates lower than 5 hz showed low reliability during non-linear, accelerated/decelerated movements, movements ${ }^{11,12}$ devices with a higher sampling rate (e.g.10hz), and coupled with $100 \mathrm{hz}$ triaxial accelerometers provided more accurate information regarding players' accelerations ${ }^{13,14}$. Therefore, strength and conditioning coaches can use this data to better plan training loads during the training process.

Previous studies indicated that physical demands vary according to playing positions in soccer. ${ }^{15,16}$. Usually, midfielders and fullbacks present a higher physical response during official matches in comparison to other positions, such as defenders ${ }^{15,16}$. Considering the specific physical responses expected for each position, it is desirable that the training process, including the SSG, provide specific stimuli to players from different positions. Indeed, Praça et al. ${ }^{8}$ confirmed that the 3 v3 SSG presents specific demands for players from different positions, which indicates the potential use of SSG for training soccer-specific content.

Furthermore, the teams' composition criteria seem to influence players'responses during SSG 4,5 . Köklü et al. ${ }^{4}$ observed that teams composed based on the players'aerobic power or based on the combination of players' aerobic power and technical skills during SSG presented a higher physical demand (i.e., distance covered at high speeds and average heart rate) compared to other criteria. This result confirms the influence of the teams' composition criteria on players'responses during SSG. Previous studies have based the teams' composition on playing positions, by choosing a defender, a midfielder, and a forward for each team ${ }^{1}$. However, to the best of our knowledge, no study has investigated the effect of the team's composition based on playing positions. On the one hand, the team's composition based on the homogeneous distribution of players from each playing position on the teams (e.g., the same number of defenders, midfielders and forwards on each team) allows the replication of specific stimuli in regard to the official matches. On the other hand, the adoption of a heterogeneous distribution (e.g., three defenders against three midfielders) could change the physical response, revealing an interesting possibility for coaches to adjust the training load in some training sessions. The present study aimed to compare the physical demands of small-sided games played by teams composed of players from the same position with teams composed of players of different positions.

\section{METHODOLOGICAL PROCEDURES Subjects}

Twelve male soccer players (age $14.43 \pm 0.16$ years; weight 62.58 $\mathrm{kg} \pm 8.72$, height $172.16 \pm 7.20 \mathrm{~cm}, 2.7$ years \pm 0.9 of time of deliberate practice), registered at the Confederação Brasileira de Futebol (CBF) participated in the study. All players belonged to the same national-level club, from the city of Curitiba. The players were selected based on their playing position, comprising three goalkeepers (not evaluated), three defenders (center-backs), three midfielders (defensive midfielders of center midfielders), and three forwards (center forwards). This study was approved by the local Ethics committee (51011915.9.0000.5149). All participants and legal guardians gave their written consent to participate in the study.

The number of participants was estimated using the software GPower 3.17, as recommended in the literature ${ }^{17}$. The dependent variable with a higher coefficient of variation (distance between 14,4 e 21,5km/h - CV= 0,062), collected during a pilot study, was used to calculate the sample size. This information was inserted at the field "t-tests for two matched groups" at the GPower software. The software recommended six subjects in order to reach and alfa of 0.05 and a beta of 0.80 . The final design of this study comprised twelve subjects, higher than the recommended by the sample size estimation procedures.

\section{Procedures}

Firstly, three teams were composed for each experimental condition, in a repeated measures design: teams composed of athletes from different positions (one defender, one midfielder, and one forward per team) - condition 1; and teams composed of athletes from the same position (e.g. three defenders) - condition 2. In addition, a control team was composed of a defender, a midfielder and a forward. This control team played against all other teams, reducing the effect of changing the opponents on the players' responses. The data provided by this team was not included in the analysis.

The athletes were allocated in each team in condition 1 according to players' performance on the field test of the System of Tactical Assessment in Soccer (FUT-SAT) ${ }^{18}$. The test comprised a 3v3 SSG, with four minutes of duration, in a $36 \times 27$ meters field. All trials were recorded and later analyzed by experts in regard to the accomplishment of the core tactical principles (offensive and defensive) ${ }^{18}$. The FUT-SAT assesses the tactical performance of each player, using the ratio between successful tactical actions and total tactical actions. Players from each playing position were ranked according to their tactical performance, which was used to compose balanced teams. Therefore, in condition 1, each team 
was composed of a player ranked second, third, and fourth, one from each playing position group. The three best players on this test were selected for the control team. Goalkeepers were randomly allocated to each team. The Table 1 presents the details of the teams' composition procedures for the two experimental conditions.

The data collection regarding the SSG comprised a two-week period. During this period, all teams played against the control team once, totalizing six sessions of data collection. All the sessions took part in a natural grass soccer field of $36 \times 27$ meters. All soccer official rules, including the offside, were adopted. All the sessions started at the same time of the day.

A Global Positioning System (GPS) (Catapult OptimEye S5, 10Hz with a triaxial $100 \mathrm{~Hz}$ accelerometer) was used to record the data regarding the physical responses of the players during the SSG. The following variables were considered for the analysis: distance covered at speeds level $1(0-7,2 \mathrm{Km} / \mathrm{h})$; distance covered at speeds level 2 (7,3-14,3Km/h); distance covered at speeds level $3(14,4-21,5 \mathrm{Km} / \mathrm{h})$; distance covered at speeds level 4 (> 21,5 Km/h); distance covered at accelerations level 1 (accelerations between $2 \mathrm{~m} / \mathrm{s}^{2}$ and $2,5 \mathrm{~m} / \mathrm{s}^{2}$ ); and distance covered at accelerations level 2 (accelerations above $2,5 \mathrm{~m} / \mathrm{s}^{2}$ ). For the distance-related variables, the values were relativized by the total distance covered during the SSG, and are expressed in percentages.

\section{Statistical analysis}

First, we checked data normality using the Shapiro-Wilk's test. We compared the variables between protocols using paired t-tests. The variable "distance level 4" presented significant deviations from normality Therefore, we used the Mann-Whitney's test to compare this variable between protocols. We also calculated the Cohen's d effect size for each comparison, which were classified as trivial $(d<0.2)$, small $(0.2<d<0.6)$, moderate $(0.6<d<1.2)$, large $(1.2<d<2.0)$, very large $(2.0<d<4.0)$, or near-perfect $(4.0<d){ }^{19}$. Considering the specificities regarding the physical skills of players from different positions in $\mathrm{SSG}^{8}$, all analyses were performed within each position and data were presented separately. The SPSS 19.0 software was used for all analyses, except for effect size. The statistical significance was set at 0.05 .

\section{RESULTS}

The defenders covered higher percentages of distance at level 1 $(p=0.001$; small effect) and level 4 ( $p=0.001$; moderate effect) in condition 2 (playing with teammates from the same position) compared to condition 1 (playing with teammates from different positions). There were no differences in the acceleration responses between conditions. In general, we found a higher physical response when defenders played with teammates from the same playing position. (Table 2)

The midfielders covered a higher percentage of distance covered at speeds level 1 ( $p=0.040$; small effect), level 3 ( $p=0.005$; moderate effect), and level 4 ( $p=0.001$; moderate effect), and a lower percentage

Table 1. Teams composed during the study,

\begin{tabular}{c|c|c|c}
\hline \multicolumn{5}{c}{ Team composition } \\
\hline \multicolumn{5}{c}{ Condition 1 } \\
\hline Team A & $\mathrm{D}^{2}$ & $\mathrm{M}^{4}$ & $\mathrm{~F}^{3}$ \\
\hline Team B & $\mathrm{D}^{3}$ & $\mathrm{M}^{2}$ & $\mathrm{~F}^{4}$ \\
\hline Team C & $\mathrm{D}^{4}$ & $\mathrm{M}^{3}$ & $\mathrm{~F}^{2}$ \\
\hline \multicolumn{5}{c}{ Condition 2 } \\
\hline Team D & $\mathrm{D}^{2}$ & $\mathrm{D}^{3}$ & $\mathrm{M}^{4}$ \\
\hline Team E & $\mathrm{M}^{2}$ & $\mathrm{M}^{3}$ & $\mathrm{~F}^{4}$ \\
\hline Team F & $\mathrm{F}^{2}$ & $\mathrm{~F}^{3}$ & $\mathrm{~F}^{1}$ \\
\hline \multicolumn{7}{c|}{ Control Team }
\end{tabular}

D: defenders; M: midfielders; F: forwards. Superscript numbers indicate the relative position of each player in the FUT-SAT test of distance covered at speeds level 2 ( $p=0.014$; moderate effect) in condition 2 compared to condition 1. There were no differences in the accelerations between conditions. In general, the condition 2 presented a higher physical demand for the midfielders, similarly to the results observed for the defenders. (Table 3)

Table 4 shows the results for forwards, which are contrary to the results previously presented for midfielders and defenders. There were no differences between conditions for any of the variables fro this playing position. Therefore, the change in the teams' composition based on the playing positions did not affect the physical responses of forwards.

Table 2. Physical responses of the defenders on the two experimental conditions.

\begin{tabular}{|c|c|c|c|c|}
\hline \multirow[b]{2}{*}{ Variables } & Condition 1 & Condition 2 & \multirow[b]{2}{*}{ p-value } & \multirow[b]{2}{*}{ Effect Size } \\
\hline & $\begin{array}{c}\text { (Players from } \\
\text { different playing } \\
\text { positions) }\end{array}$ & $\begin{array}{c}\text { (Players from the } \\
\text { same playing } \\
\text { position) }\end{array}$ & & \\
\hline Total Distance & $428.63(65.30)$ & $445.92(42.36)$ & 0.333 & 0.301 \\
\hline Distances level 1 & $0.44(0.06)$ & $0.46(0.06)$ & $0.001^{*}$ & 0.333 \\
\hline Distances level 2 & $0.42(0.06)$ & $0.34(0.11)$ & 0.078 & $0.838^{\&}$ \\
\hline Distances level 3 & $0.14(0.05)$ & $0.14(0.05)$ & 0.690 & 0.001 \\
\hline Distances level 4 & $0.00(0.00)$ & $0.04(0.04)$ & $0.001^{*}$ & $1.000^{\&}$ \\
\hline Accelerations level 1 & $50.08(7.06)$ & $47.58(5.98)$ & 0.102 & 0.379 \\
\hline Accelerations level 2 & $99.50(4.95)$ & $101.92(5.63)$ & 0.093 & 0.454 \\
\hline
\end{tabular}

*Valores significativos; \& efeitos moderados.

Table 3. Physical responses of the midfielders on the two experimental conditions.

\begin{tabular}{|c|c|c|c|c|}
\hline \multirow[b]{2}{*}{ Variables } & Condition 1 & Condition 2 & \multirow[b]{2}{*}{ p-value } & \multirow[b]{2}{*}{ Effect Size } \\
\hline & $\begin{array}{c}\text { (Players from } \\
\text { different playing } \\
\text { positions) }\end{array}$ & $\begin{array}{c}\text { (Players from the } \\
\text { same playing } \\
\text { position) }\end{array}$ & & \\
\hline Total Distance & $422.88(38.12)$ & $437.96(30.97)$ & 0.131 & 0.429 \\
\hline Distances level 1 & $0.46(0.07)$ & $0.48(0.06)$ & $0.040^{*}$ & 0.304 \\
\hline Distances level 2 & $0.41(0.07)$ & $0.32(0.08)$ & $0.014^{*}$ & $1.190^{\&}$ \\
\hline Distances level 3 & $0.12(0.04)$ & $0.15(0.04)$ & $0.005^{*}$ & $0.750^{\&}$ \\
\hline Distances level 4 & $0.01(0.01)$ & $0.04(0.04)$ & $0.001^{*}$ & $0.832^{\&}$ \\
\hline Accelerations level 1 & $49.00(6.39)$ & $50.96(5.60)$ & 0.246 & 0.324 \\
\hline Accelerations level 2 & $98.08(6.04)$ & $99.92(6.15)$ & 0.354 & 0.301 \\
\hline
\end{tabular}

Table 4. Physical responses of the forwards on the two experimental conditions.

\begin{tabular}{|c|c|c|c|c|}
\hline \multirow[b]{2}{*}{ Variables } & Condition 1 & Condition 2 & \multirow[b]{2}{*}{ p-value } & \multirow[b]{2}{*}{ Effect Size } \\
\hline & $\begin{array}{c}\text { (Players from } \\
\text { different playing } \\
\text { positions) }\end{array}$ & $\begin{array}{c}\text { (Players from the } \\
\text { same playing } \\
\text { position) }\end{array}$ & & \\
\hline Total Distance & $439.46(36.47)$ & $426.63(29.87)$ & 0.206 & 0.381 \\
\hline Distances level 1 & $0.45(0.05)$ & $0.46(0.06)$ & 0.687 & 0.179 \\
\hline Distances level 2 & $0.41(0.05)$ & $0.41(0.06)$ & 0.743 & 0.000 \\
\hline Distances level 3 & $0.14(0.04)$ & $0.12(0.03)$ & 0.178 & 0.554 \\
\hline Distances level 4 & $0.01(0.01)$ & $0.01(0.02)$ & 0.267 & 0.000 \\
\hline Accelerations level 1 & $47.75(6.85)$ & $49.71(7.05)$ & 0.422 & 0.281 \\
\hline Accelerations level 2 & $98.17(5.02)$ & $99.92(6.15)$ & 0.343 & 0.308 \\
\hline
\end{tabular}

\section{DISCUSSION}

This study aimed to analyze the influence of changing the teams' composition criteria, based on the players' playing position, on players' physical responses during soccer SSG. In general, playing with teammates from the same position increases the physical responses of defenders and midfielders, although it does not affect forwards' responses.

Previous studies showed differences in players' behavior when the teams were formed according to different composition criterion ${ }^{4,5}$. In this study, the SSG played by teams composed of athletes from the same playing position presented an increased physical demand compared to SSG played by teams composed of athletes of different playing positions. It 
has been suggested that players from different positions present different physical, anthropometrical, technical, and tactical skills, which justify the specific behaviors observed in both official matches $15,16,20$ and training situations ${ }^{8,21,22}$. Therefore, we suggest that in the SSG played by teams composed of a defender, a midfielder and a forward, which is usually adopted in the literature ${ }^{8,23}$, players kept a similar playing dynamics compared to official matches. In contrast, when teams are composed of players from the same playing position, players are demanded to perform different non-specific actions in relation to what is expected in the commom teams' composition (defender-midfielder-forward) in both official matches and training sessions. This modification would lead, therefore, to an increased physical demand, which is in line with our results. However, the lack of influence of teams' composition on forwards physical responses, may be related to the heterogeneous physical, anthropometrical, and tactical-technical characteristics of these players (for example, center forwards and wings).Future studies should improve the comprehension of this phenomenon.

The choice of different SSG formats for each training session reflects the interest of the coaching staff to achieve specific training loads ${ }^{24}$. The results of the present study allow a better understanding of the use of the 3V3 SSG during soccer training. Specifically, if the coaching staff aims to increase the physical demands of the training, we suggest the adoption of teams composed of players from the same playing position. Moreover, considering the importance of avoiding the premature specialization of youth players during the early years of deliberate practice in soccer and guarantee a diversity of tactical and technical stimuli 25,26, we also suggest that the use of SSG with athletes from the same playing position allows a better pedagogical environment for teaching general, operational, and core tactical principles of soccer. Future studies should focus on the assessment of tactical behavior during SSG played by teams formed according to different teams' composition criteria, to reach a better comprehension of this variable on players' responses.

The novelty of this study regards the effects of the teams' composition criteria based on the players' playing positions on players' responses during SSG. few suggest future studies to investigate different participants (ages and levels of expertise). In addition, considering that the number of players per team influences the players'behavior during SSG 27,28, future studies should investigate the effect of the independent variable "teams' composition criterion" on players' physical responses within larger SSG formats.

\section{CONCLUSION}

We concluded that the teams' composition criterion influences the physical demands of the 3v3 SSG. Playing with teammates from the same position increases the physical responses of defenders and midfielders.

\section{ACKNOWLEDGMENTS}

We are grateful to Fundação de Amparo à pesquisa do estado de Minas Gerais (FAPEMIG), Conselho Nacional de Desenvolvimento Científico eTecnológico (CNPq), and Pró-reitoria de Pesquisa (PRPq) da Universidade Federal de Minas Gerais for financial support.

\section{All authors declare no potential conflict of interest related to this article}

AUTHORS' CONTRIBUTIONS: Each author contributed individually and significantly to the development of the manuscript. Gibson Moreira Praça: writing, data collection, and data analysis; Marcelo Vilhena Silva: writing, data collection, and data analysis; Raphael Brito e Sousa: data analysis and revision, Juan Carlos Pérez Morales: data analysis and revision; Pablo Juan Greco: critical review, project planning.

\section{REFERENCES}

1. Praça GM, Custódio IJ, Greco PJ. Numerical superiority changes the physical demands of soccer players during smallsided games. Rev Bras Cineantropom Desempenho Hum. 2015;17(3): 269-79.

2. Aguiar M, Botelho G, Lago C, Maças V, Sampaio J. A review on the effects of soccer small-sided games. J Hum Kinet. 2012;33:103-13.

3. Casamichana D, Castellano J. Time-motion, heart rate, perceptual and motor behaviour demands in small-sides soccer games: Effects of pitch size. J Sports Sci. 2010;28(14):1615-23.

4. KöklüY, ErsöZ G, Alemdaroglu U, Aş̧̧ A, Özkan A. Physiological responses and time-motion characteristics of 4-A-side small-sided game in young soccer players: the influence of different team formation methods. J Strength Cond Res. 2012;26(11):3118-23.

5. Praça GM, Morales JC, Moreira PE, Peixoto GH, Bredt ST, Chagas MH, et al. Tactical behavior in socce small-sided games: inluence of team composition criteria. Rev Bras Cineantropom Desempenho Hum. 2017;19(3): 354-363.

6. Praça GM, Clemente FM, Andrade AG, Morales JC, Greco PJ. Network analysis in small-sided and conditioned soccer games: The influence of additional players and playing position. Kinesiology. 2017;49(2): 185-193.

7. Casamichana D, Román-Quintana JS, Calleja-González J, Castellano J. Utilización de la limitación de contactos en el entrenamiento en fútbol: ¿afecta a las demandas físicas y fisiológicas? Rev Int Cienc Deport. 2013;9(33): 208-221

8. Praça G, Custodio IJ, Silva MV, Andrade AG, Greco PJ. Demandas físicas são influenciadas pelo estatuto posicional em pequenos jogos? Rev Bras Med Esporte. 2017;23(5):399-402.

9. Dellal A, Drust B, Lago-Penas C. Variation of activity demands in small-sided soccer games. Int J Sports Med. 2012;33(5):370-5

10. Hodgson C, Akenhead R, Thomas K. Time-motion analysis of acceleration demands of $4 \mathrm{v} 4$ small-sided soccer games played on different pitch sizes. Hum Mov Sci. 2014;33:25-32.

11. Gray AJ, Jenkins D, Andrews MH, Taaffe DR, Glover ML. Validity and reliability of GPS for measuring distance travelled in field-based team sports. J Sports Sci. 2010;28(12): 1319-25.

12. Jennings D, CormackS, Coutts AJ, Boyd L, Aughey RJ. The validity and reliability of GPS units for measuring distance in team sport specific running patterns. Int J Physiol Perform. 2010;5(3):328-41.

13. Buchheit M, Haddad HA, Simpson BM, Palazzi D, Bourdon PC, Di Salvo V, et al. Monitoring Accelerations With GPS in Football: Time to Slow Down? Int J Sports Physiol Perform. 2014;9(3):442-5.

14. Varley MC, Fairweather $I H$, Aughey RJ.Validity and reliability of GPS for measuring instantaneous velocity during acceleration, deceleration, and constant motion. J Sports Sci. 2012;30(2):121-7.

15. Bush M, Barnes C, Archer DT, Hogg B, Bradley P. Evolution of match performance parameters for various playing positions in the English Premier League. Hum Mov Scien. 2015;39:1-11.

16. Di Salvo V, Baron R, Tschan H, Calderon Montero FJ, Bachl N, Pigozzi F. Performance characteristics according to playing position in elite soccer. Int J Sport Med. 2007;28(3):222-7.

17. Beck TW. The importance of a priori sample size estimation in strength and conditioning research. $J$ Strength Cond Res. 2013;27(8):2323-37.

18. Costa IT, Garganta JM, Greco PJ, Mesquita I, Maia J. System of tactical assessment in Soccer (FUT-SAT): Development and preliminary validation. Motricidade. 2011;7(1):69-83.

19. Cohen J. Statistical power analysis for the behavioral sciences. 2 nd ed. Hillsdale, NJ: Lawrence Erlbaum Associates Publishers; 1988

20. Goncalves BV, Figueira BE, Macãs V, Sampaio J. Effect of player position on movement behaviour, physical and physiological performances during an 11-a-side football game. J Sports Sci. 2014;32(2):191-9.

21. Praça GM, Pérez-Morales JC, Greco PJ. Influência do estatuto posicional no comportamento tático durante jogos reduzidos no futebol: um estudo de caso em atletas sub-17 de elite. Rev Port Cien Desporto. 2016;16(S2A):194-206.

22. Padilha MB, Moraes JC, Costa IT. O estatuto posicional pode influenciar o desempenho tático ente jogadores da categoria sub-13? Rev Bras Cien Mov. 2013;21(4):73-9.

23. Praça GM, Folgado $\mathrm{H}$, Andrade AG, Greco PJ. Influence of additional players on collective tactical behavior in small-sided soccer games. Rev Bras Cineantropom Desempenho Hum. 2016;18(1):62-71.

24. Clemente FM, Martins FM, Mendes RS. Periodization based on small-sided soccer games: theoretical considerations. Strength Cond J. 2014;36(5):34-43.

25. Greco PJ, Morales JC, Aburachid LM, Lopes M, Silva SR, Benda RN. Iniciação Esportiva Universal: O jogo do "ABC" na alfabetização esportiva. In: Lemos K, Greco PJ, Morales JC (editors). $5^{\circ}$ Congresso Internacional dos Jogos Desportivos. Belo Horizonte: Casa da Educação Física; 2015. p. 335-59.

26. Greco PJ, Benda RN. Iniciação Esportiva Universal. Belo Horizonte: UFMG; 1998.

27. Vickery W, Dascombe B, Duffield R, Kellett A, Portus M. The influence of field size, player number and rule changes on the physiological responses and movement demands of small-sided games for cricket training. J Sports Sci. 2013;31(6):629-38.

28. Vilar L, Esteves PT, Travassos B, Passos P, Lago-Penas C, Davids K. Varying Numbers of Players in Small-Sided Soccer Games Modifies Action Opportunities During Training. Int J Sports Sci Coach. 2014;9(5):1007-18 